\title{
Intrusive Dislocation in Permanent Teeth: Review of Literature and Clinical Case Report
}

\author{
Luxación Intrusiva en Dientes Permanentes: \\ Revisión de Literatura e Informe de Caso Clínico
}

\begin{abstract}
Renata de Almeida Braga'; Willian Douglas França Braga'; Caroline Felipe Magalhães Girelli; Mariane Floriano Lopes Lacerda ${ }^{3}$; Renato Girelli Coelho ${ }^{4} \&$ Rafael Binato Junqueira ${ }^{3}$
\end{abstract}

BRAGA, R. A.; BRAGA, W. D. F.; GIRELLI, C. F. M.; LACERDA, M. F. L.; COELHO, R. G. \& JUNQUEIRA, R. B. Intrusive dislocation in permanent teeth: Review of literature and clinical case report. Int. J. Odontostomat., 13(1):89-92, 2019.

ABSTRACT: Intrusive dislocation is an unusual and severe trauma, where the tooth is displaced axially into the alveolar bone, causing damage to the periodontal and pulpal tissues. The objective was to report a case of intrusive dislocation on a right maxillary central incisor of a 12-year-old patient, where the proposed treatment was immediate surgical repositioning. Clinical and radiographic examination revealed partial tooth intrusion and complete root formation. The impacted tooth was surgically repositioned and immobilized. Subsequently, the endodontic treatment of the tooth associated with intracanal medication was performed. After 10 months of successive calcium hydroxide changes, the root canal system was filled. Clinical-radiographic follow-ups were performed over 5 years and 7 months, revealing discrete root resorption. It was concluded that immediate surgical repositioning, associated with adequate root canal therapy may be an effective therapeutic option in cases of intrusive dislocation of permanent teeth.

KEY WORDS: intrusion, dental trauma, surgical repositioning.

\section{INTRODUCTION}

Intrusive dislocation is defined as the axial displacement of a tooth into the alveolus, affecting mainly the upper central incisors, followed by the upper lateral incisors and rarely occurring in the mandible teeth (Dias et al., 2009; Gupta, 2011).

Despite its low prevalence, which corresponds to $1.9 \%$ to $3 \%$ of all traumatic lesions, intrusive dislocation is considered one of the most severe forms, which can produce catastrophic damage to the alveolar bone, severe shearing, gingival fibers rupture, periodontal ligament cells destruction, as well as crushing of the apical neurovascular system (Erverdi \& Kargül, 2002; Güngör et al., 2006; Dias et al.; Gomes et al., 2013).

\section{This trauma can generate serious}

consequences such as root resorption, loss of bone and gingival insertion, and impairment in the root development of cases with incomplete rhizogenesis. Pulp necrosis is reported in $100 \%$ of cases with a completely closed apex (Andreasen et al., 2006a; Güngör et al.). The recommended treatments based on clinical and radiographic signs and symptoms may include, passive repositioning, where the tooth returns itself to its primary position, immediate surgical repositioning and active repositioning with dental traction by orthodontic devices (Gomes et al.).

The objective of this study was to describe a clinical case of intrusive dislocation, highlighting the adopted protocol and the results obtained after clinical and radiographic 5 years and 7 months' follow-up.

\footnotetext{
${ }^{1}$ Students of the Specialization Course in Endodontics, Brazilian Association of Dentistry -ABO / GV-Governador Valadares, MG, Brazil.

${ }^{2}$ Master of the Specialization Course in Endodontics, Brazilian Association of Dentistry -ABO / GV-Governador Valadares, MG, Brazil

${ }^{3}$ Doctor of the Department of Dentistry, Juiz de Fora University, Governador Valadares-UFJF / GV campus, Governador Valadares, MG, Brazil.

${ }^{4}$ Doctor of the Department of Dentistry at the Vale do Rio Doce University (UNIVALE), Coordinator and professor of the dental improvement courses at $\mathrm{ABO} / \mathrm{GV}$.
} 
BRAGA, R. A.; BRAGA, W. D. F.; GIRELLI, C. F. M.; LACERDA, M. F. L.; COELHO, R. G. \& JUNQUEIRA, R. B. Intrusive dislocation in permanent teeth: Review of literature and clinical case report. Int. J. Odontostomat., 13(1):89-92, 2019

\section{CASE REPORT}

A 12-year-old male patient attended the dental office on Dec 6th, 2011 at 07:30 a.m., after suffering trauma in the anterior region of the maxilla. During the clinical history interview, the person responsible for the patient reported that the injury occurred after a table was pushed toward him.

The intraoral examination revealed that the patient was using an orthodontic appliance, a partial intrusion of the right maxillary central incisor, lacerated lower lip with edema, but no suture was required in the region (Fig. 1). Periapical radiography showed complete root formation. When performing the pulpal sensitivity tests with the cold stimulus, the left maxillary central incisor presented a positive result, indicating pulp normality. Nevertheless, on the right maxillary central incisor, the response was negative, suggesting pulp necrosis. The patient was referred to the orthodontist to remove the orthodontic appliance. After 10 hours of the accident, we opted for immediate surgical repositioning of the right maxillary central incisor. Anesthesia of the maxillary anterior alveolar nerve was performed, and a manual (digital) reposition was attempted. Due to not enough coronary structure, there was no success in the maneuver. Thus, after careful handling, the tooth was surgically repositioned with the aid of a $N^{\circ} 151$ forceps, where its active tip was inserted near the junction of the crown and root. After repositioning the tooth, the tissues were immobilized through interdental 4.0 sutures and a semirigid splint was performed with $0.40 \mathrm{~mm}$ orthodontic wire and light-curing composite resin Z250 (3M ESPE), extending from right maxillary canine to left maxillary lateral incisor (Fig. 2). The patient was instructed to have a liquid and semi-solid diet and to maintain care with oral hygiene. Antibiotic and analgesic coverage with amoxicillin $500 \mathrm{mg}$ and sodium dipyrone $500 \mathrm{mg}$ respectively. After 10 days, the splint was removed and no mobility was observed (Fig 2).

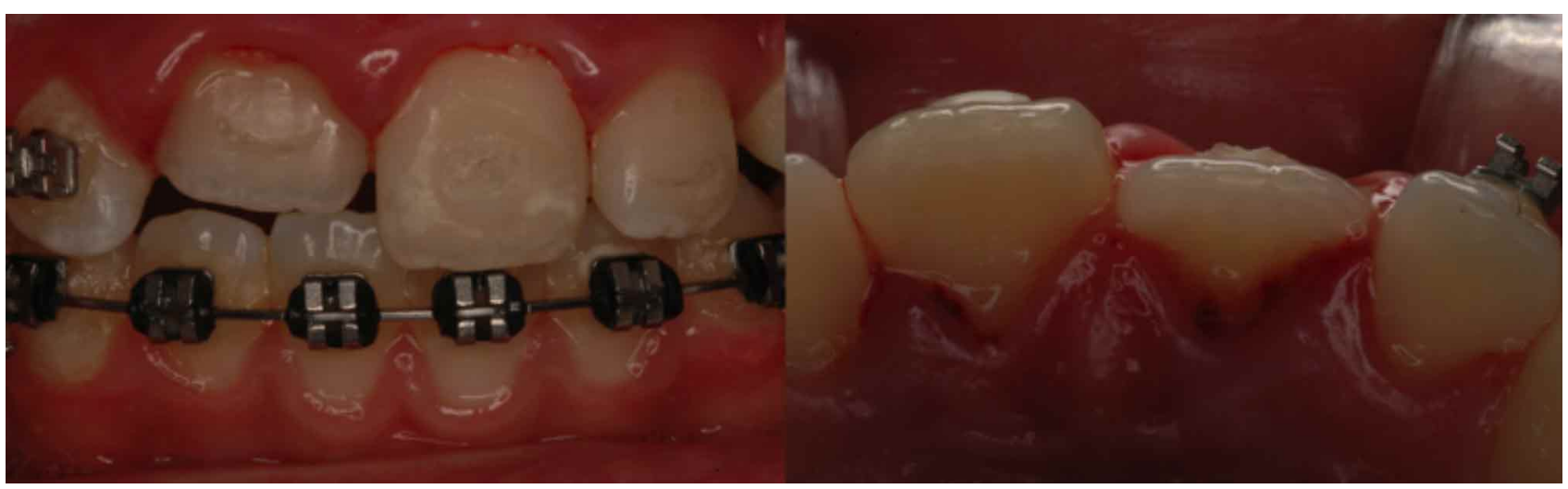

Fig. 1. Initial clinical aspect of tooth 11. Oral and palatal view.


Fig. 2. Orthodontic contention placed immediately after trauma (A) and after 10 days (B). Final aspect after contention removal (C).

After 14 days of the accident, tissue healing occurred, the cold stimulus' pulp sensitivity test was performed and pulp necrosis of the right maxillary central incisor was confirmed, whereby endodontic therapy was started. Absolute isolation, pulp chamber opening, pre-enlargement, manual instrumentation using the Ruddle's technique, irrigation with $5.25 \%$ sodium hypochlorite, calcium hydroxide (Biodynamic, Ibiporã, 
Paraná, Brazil) was carried out in distilled water as intracanal medication to finally seal the access with a sterile cotton pellet and temporary cement (Obtur Maquira, Maringá, Paraná, Brazil). The patient returned after 21 days, when was clinically observed tooth discoloration on the left maxillary central incisor, whereby, pulp sensitivity test was performed, diagnosing pulp necrosis thus indicating endodontic intervention according to previously described protocol. Initially, the calcium hydroxide paste was exchanged in both teeth every month, and after every
3 months, in order to avoid inflammatory root resorption. After 10 months of the accident, the thermoplastic filling was performed using gutta-percha cones and endodontic sealer based on zinc oxide and eugenol (Pulp Canal Sealer - Sybronendo, Joinville, Santa Catarina, Brazil) (Fig. 3).

The patient returned for clinical and radiographic follow-ups of both teeth on April 4th, 2013, March 11th, 2015 and June 9th, 2018. The radiographic examination revealed a slight root resorption (Fig. 3).
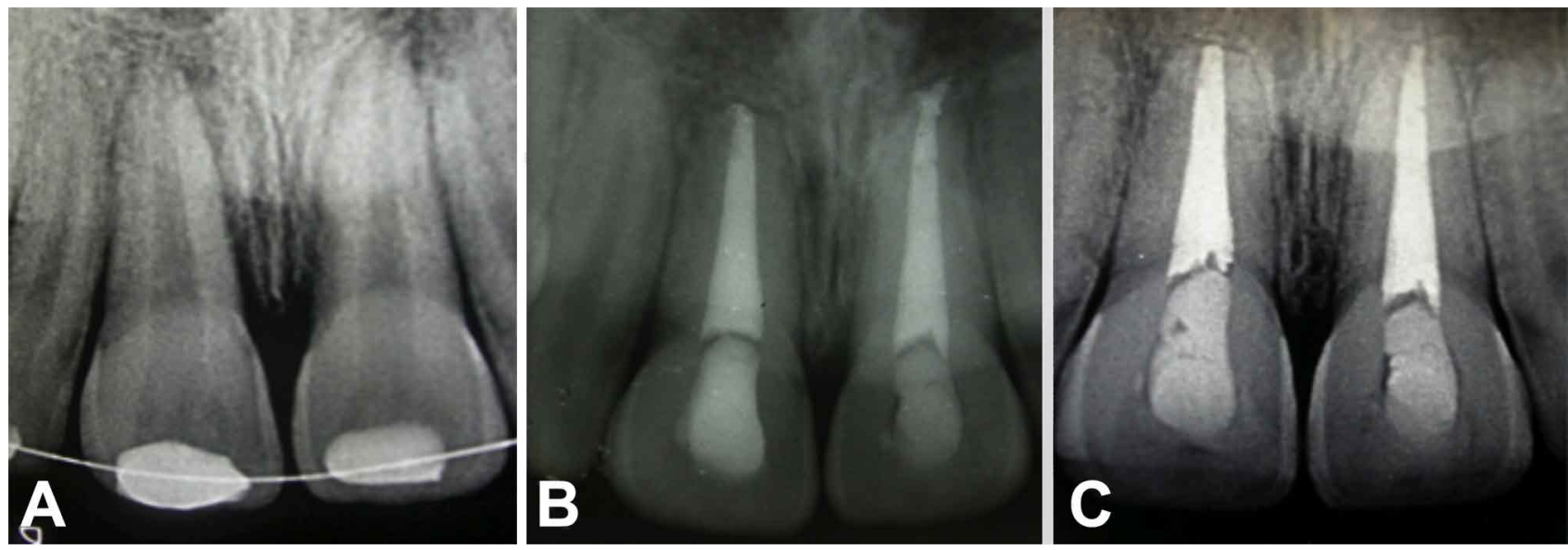

Fig. 3. Initial radiography (A); final radiography $(B)$ and radiographic proservation after 3 years and 3 months (C).

\section{DISCUSSION}

Intrusive dislocation is the most severe form of dental trauma, resulting in an unfavorable prognosis and requiring more complex treatment. Thus, endodontic intervention should be started as early as possible to avoid possible complications (Güngör et al.; de Alencar et al., 2007; Costa et al., 2017). Complications observed in teeth that have suffered intrusive dislocation include pulp necrosis and external root resorption, as well as ankylosis, bone loss and root canal obliteration (Chaushu et al., 2004; Dias et al.). However, clinical studies in the literature on intrusive dislocation are scarce and there is no consensus on the treatment of intruded permanent teeth which will be determined by clinical and radiographic diagnosis (Andreasen et al., 2006b; Güngör et al.; Dias et al.; Gomes et al.). At the moment of the radiographic examination, the disappearance of the periodontal ligament space and the height difference between the vertices of the traumatized teeth can be verified. In addition, the degree of root formation and eventual bone fracture can also be determined (Gomes et al.).
Recommended treatment options for intruded teeth include: 1.- re-eruption of teeth with open or closed apices in patients 12 to 17 years of age, with an intrusion up to $7 \mathrm{~mm}$, due to their high eruption potential; 2.immediate surgical repositioning with fixation, indicated for teeth with closed apices and greater than $7 \mathrm{~mm}$ intrusions, in patients from 12 to 17 years, as well as for patients over 17 years; 3 .- Orthodontic extrusion is performed on teeth with a closed apex, with intrusion between 3 to $6 \mathrm{~mm}$, it allows the remodeling of bone and periodontal tissues, and may also be indicated in cases of teeth with open apex (Erverdi \& Kargül; Güngör et al.; Dias et al.; Gomes et al.).

It has been suggested in the literature that in a less than $3 \mathrm{~mm}$ intrusions cases, orthodontic extrusion is a technique that provides good results (Güngör et al.).

In the present case, immediate surgical repositioning was the treatment of choice due to the severity of the intrusion and to the complete root formation, since it is a technique that favors the return of 
the adjacent tissues to the original anatomical situation in order to allow repair and the adequate access to endodontics (Güngör et al.; de Alencar et al.; Dias et al.; Costa et al.). In the 10-day period, the root was stabilized at the new position, which was the time required to avoid dehydration of the root surface cells, because it could lead to root anchylosis and root resorption (Erverdi \& Kargül).

Intrusive dislocation in permanent teeth with complete root formation provides a great risk of root resorption and loss of pulp vitality (Gomes et al.). In this study, tooth endodontic treatment of right maxillary central incisor was started after 14 days of trauma. Subsequent to the mechanical-chemical preparation of the root canal system, calcium hydroxide paste was placed. In the present case, the intracanal medication was maintained up to 10 months, being periodically changed to finally fill the canal.

Calcium hydroxide is used to prevent inflammatory root resorption, and there is no consensus in the literature about the optimal time to maintain it (Andreasen et al., 2006c; de Alencar et al.; Costa et al.). However, it is suggested that the dressing would be maintained for 6 to 9 months (de Alencar et al.).

According to Güngör et al. the time interval of a repositioning lesion of displaced teeth seems to be related to resorption of the root surface. In this case, the tooth reposition time was approximately 10 hours. This reduced theduration of intimate contact of the root with the alveolar bone. It has been reported that compression of the root against the alveolar bones and delayed repositioning facilitates root resorption.

In the present case, a slight root resorption was observed after 5 years and 7 months of treatment and follow-up.

CONCLUSION. In view of these results, surgical repositioning, associated with adequate root canal therapy, may be an effective therapeutic option in cases of permanent tooth intrusive dislocations.

BRAGA, R. A.; BRAGA, W. D. F.; GIRELLI, C. F. M.; LACERDA, M. F. L.; COELHO, R. G. \& JUNQUEIRA, R. B. Luxación intrusiva en dientes permanentes: Revisión de literatura e informe de caso clínico. Int. J. Odontostomat., 13(1):89-92, 2019,

RESUMEN: La luxación intrusiva es un trauma inusual y severo, en el que el diente se desplaza axialmente hacia el hueso alveolar, causando daño a los tejidos periodontales y pulpares. El objetivo fue informar un caso de luxación intrusiva en un incisi- vo central superior derecho de un paciente de 12 años, donde el tratamiento propuesto fue el reposicionamiento quirúrgico inmediato. El examen clínico y radiográfico reveló una intrusión dental parcial y la formación completa de la raíz. El diente afectado fue reposicionado e inmovilizado quirúrgicamente. Posteriormente, se realizó el tratamiento endodóntico del diente asociado con la medicación intracanal. Después de 10 meses de sucesivos cambios de hidróxido de calcio, se llenó el sistema de conductos radiculares. Los seguimientos clínico-radiográficos se realizaron durante 5 años y 7 meses, revelando la resorción discreta de la raíz. Se concluyó que el reposicionamiento quirúrgico inmediato, asociado con la terapia adecuada del conducto radicular, puede ser una opción terapéutica efectiva en casos de luxación intrusiva de dientes permanentes.

PALABRAS CLAVE: intrusión, trauma dental, reposicionamiento quirúrgico.

\section{REFERENCES}

Andreasen, J. O.; Bakland, L. K. \& Andreasen, F. M. Traumatic intrusion of permanent teeth. Part 3. A clinical study of the effect of treatment variables such as treatment delay, method of repositioning, type of splint, length of splinting and antibiotics on 140 teeth. Dent. Traumatol., 22(2):99-111, 2006.

Andreasen, J. O.; Bakland, L. K. \& Andreasen, F. M. Traumatic intrusion of permanent teeth. Part 2. A clinical study of the effect of preinjury and injury factors, such as sex, age, stage of root development, tooth location, and extent of injury including number of intruded teeth on 140 intruded permanent teeth. Dent. Traumatol., 22(2):90-8, 2006.

Andreasen, J. O.; Bakland, L. K.; Matras, R. C. \& Andreasen, F. M. Traumatic intrusion of permanent teeth. Part 1. An epidemiological study of 216 intruded permanent teeth. Dent. Traumatol., 22(2):83-9, 2006.

Chaushu, S.; Shapira, J.; Heling, I. \& Becker, A. Emergency orthodontic treatment after the traumatic intrusive luxation of maxillary incisors. Am. J. Orthod. Dentofacial Orthop., 126(2):162-72, 2004.

Costa, L. A.; Ribeiro, C. C.; Cantanhede, L. M.; Santiago Júnior, J. F.; de Mendonça, M. R. \& Pereira, A. L. Treatments for intrusive luxation in permanent teeth: a systematic review and meta-analysis. Int. J. Oral Maxillofac. Surg., 46(2):214-29, 2017.

de Alencar, A. H.; Lustosa-Pereira, A.; de Sousa, H. A. \& Figueiredo, J. H. Intrusive luxation: a case report. Dent. Traumatol., 23(5):307-12, 2007.

Dias, R. S.; Cajazeira Neto, J. A.; de Carvalho, F. M. \& Moreira Neto, J. J. Surgical repositioning of a traumatically intruded permanent incisor in a patient with rheumatic fever: case report. Dent. Traumatol., 25(1):e12-5, 2009.

Erverdi, N. \& Kargül, B. Complete intrusion of maxillary permanent central incisors. J. Clin. Pediatr. Dent., 27(1):9-11, 2002.

Gomes, G. B.; da Costa, C. T. \& Bonow, M. L. Traumatic intrusion of permanent teeth: 10 years follow-up of 2 cases. Dent. Traumatol., 29(2):165-9, 2013.

Güngör, H. C.; Cengiz, S. B. \& Altay, N. Immediate surgical repositioning following intrusive luxation: a case report and review of the literature. Dent. Traumatol., 22(6):340-4, 2006.

Gupta, M. Intrusive luxation in primary teeth - Review of literature and report of a case. Saudi Dent. J., 23(4):167-76, 2011.

Corresponding author:

Dr. Rafael Binato Junqueira

Avenida: Doutor Raimundo Rezende, 330

Centro, Gov. Valadares

MG, 35012-140

BRAZIL

Received: $25-11-2018$

Accepted: 07-12-2018

E-mail: binatojunqueira@gmail.com 